\title{
A Postnatal Change in the Immunological Properties of the Acetylcholine Receptor at Rat Muscle Endplates ${ }^{1}$
}

\author{
ZACH W. HALL,; PAMELA D. GORIN, LAURA SILBERSTEIN, ${ }^{3}$ and CHARIS BENNETT \\ Division of Neurobiology, Department of Physiology, School of Medicine, University of California, San Francisco, California 94143
}

\begin{abstract}
We have used a myasthenic serum that in adult rat muscle is specific for acetylcholine receptors (AChRs) in the extrajunctional membrane to characterize the AChRs at developing endplates. Immunocytochemical experiments show that AChRs at endplates in the rat diaphragm bind the myasthenic antibodies during the first week after birth but lose their reactivity during the second and third postnatal weeks. AChRs at endplates in adult rat diaphragm do not bind the antibodies even after denervation; in contrast, AChRs at endplates in an adult chicken muscle (anterior latissimus dorsi) are recognized by the antibodies. The loss of immunological reactivity thus may be correlated with a change in the channel properties of the AChR and with the appearance of synaptic folds, two postnatal developmental changes that occur at the endplates of rats, but not of chickens.
\end{abstract}

Formation of the mature mammalian neuromuscular junction occurs in several stages during embryonic and early postnatal life (Dennis, 1981). During this period, the acetylcholine receptor (AChR) changes its distribution on the muscle surface, and AChRs at the new endplates change several of their properties (Fambrough, 1979). The first sign of differentiation at the developing endplates is the appearance of AChR clusters near the nerve terminals. In the rat, these clusters appear at embryonic day 15 , about $48 \mathrm{hr}$ after the initial functional contact between nerve and muscle (Bevan and Steinbach, 1977; Braithwaite and Harris, 1979; Dennis et al., 1981). The AChRs at the new endplates initially have a rapid metabolic turnover time, like those of AChRs in the extrajunctional membrane, but undergo metabolic stabilization just before birth (Reiness and Weinberg, 1981). A further stage of synaptic development occurs in the rat after birth: the mean channel open time of the AChRs decreases (Sakmann and Brenner, 1978; Fischbach and Schuetze, 1980; Michler and Sakmann, 1980) and the postsynaptic membrane develops folds (Teravainen, 1968; Kelly and Zacks, 1969). A comparison of the biochemical properties of AChRs purified from adult endplates with those derived from the extrasynaptic membranes of denervated or embryonic muscles shows them to be closely similar (Brockes and Hall, 1975; Nathanson and Hall, 1979). The two can

Received May 4, 1984; Revised August 20, 1984;

Accepted August 22, 1984

\footnotetext{
${ }^{1}$ We thank Dr. Peter Dau, now at Evanston Hospital, Evanston, IL, for providing us with myasthenic sera, Ms. Nicole Robitaille-Giguere for expert technical assistance, and Ms. Kem Wefer for typing the manuscript. We are also grateful to Dr. A. J. Hudspeth for a crucial suggestion and for comments on the manuscript. This work was supported by grants from the National Institutes of Health and from the Muscular Dystrophy Association.

${ }^{2}$ To whom correspondence should be addressed.

${ }^{3}$ Present address: Department of Pharmacology, Stanford Medical School, Stanford, CA 94305.
}

be distinguished, however, by antibodies in the serum of patients with myasthenia gravis (Almon and Appel, 1975; Weinberg and Hall, 1979; Dwyer et al., 1981). We have used a highly specific myasthenic serum to show that $A C h R s$ at developing endplates in the rat initially resemble the AChRs in the extrasynaptic membrane but later change their immunological properties. This change occurs at approximately the same time as the channel properties of the AChR change and the folds appear.

Some of these findings have been reported in preliminary form (Hall et al., 1983)

\section{Materials and Methods}

AChR. AchRs were partially purified from normal and denervated (10 days) rat muscle on a cobra toxin affinity column as described by Froehner et al. (1977), except that the AChR was eluted from the column in $1 \%$ Triton $X-100$ instead of deoxycholate. For assay, AChRs were incubated with [ $\left.{ }^{225} \mid\right]$ $-\alpha$-bungarotoxin $\left({ }^{125}\right]-\alpha$-BuTx) and toxin-receptor complex formation was measured using a DEAE-cellulose filtration assay (Brockes and Hall, 1975). The amount of AChR is expressed as femtomoles of toxin-binding sites.

Myasthenic antibodies. In the initial set of experiments, we used myasthenic sera that were provided by Dr. Peter Dau, who obtained them at Children's Hospital, San Francisco, during the period 1973 to 1978, using a protocol approved by the Human Studies Committee, University of California, San Francisco. In later experiments, we used antibodies from a plasmapheresis serum laken by Dr. Dau that had beer stored for 4 years as a $40 \%$ ammonium sulfate fraction. This fraction was subsequently dialyzed in our laboratory against $0.02 \mathrm{M}$ ammonium bicarbonate, lyophilized, and stored at $-20^{\circ} \mathrm{C}$. Solutions were made from this stock as needed.

For immunocytochemistry experiments, a DEAE fraction was prepared as follows. The lyophilized protein $(60 \mathrm{mg})$ was taken up in $3 \mathrm{ml}$ of $10 \mathrm{~mm}$ potassium phosphate, $\mathrm{pH} 8.0$, and passed over a 3-ml DE-52 (Whatman) column equilibrated in the same buffer. Aliquots of the column pass-through were then stored at $-80^{\circ} \mathrm{C}$ for future use.

Assays. To measure inhibition of toxin binding, several microliters of each serum were incubated overnight at $4^{\circ} \mathrm{C}$ with $125 \mathrm{fmol}$ of AChR purified from normal or denervated rat muscle. $\left.\left[{ }^{125}\right]\right]-\alpha-B u T x$ was added to a final concentration of $10 \mathrm{nM}$ in a volume of $30 \mu \mathrm{l}$ and the incubation continued at $37^{\circ} \mathrm{C}$ for $60 \mathrm{~min}$. Toxin-receptor complex formation was then measured by a filtration assay as described above.

Binding of antibodies in the serum to the AChR was measured directly by incubating $200 \mathrm{fmol}$ of $\mathrm{AChR}$ with serum overnight at $4^{\circ} \mathrm{C}$ in a solution (30 $\mu$ ) containing phosphate-buffered serum (PBS) with $1 \%$ Triton X-100 and 1 $\mathrm{mg} / \mathrm{ml}$ of bovine serum albumin (BSA). Fifty microliters of a $20 \%$ suspension of immobilized protein A (IgG Sorb, The Enzyme Center, Inc.) in $40 \mathrm{~mm} \mathrm{NaCl}$, $5 \mathrm{~mm}$ EDTA, $10 \mathrm{~mm}$ Tris, $1 \%$ Triton $\mathrm{X}-100,0.02 \% \mathrm{NaN}_{3}(\mathrm{pH} 8.0)$ were added and the incubation continued at room temperature for $60 \mathrm{~min}$. Samples were centrifuged, and duplicate 20- $\mu$ l samples of the supernatant were assayed for remaining AChR using the DEAE filtration assay described above.

The effect of $\alpha$-BuTx on binding of antibodies from the plasmapheresis serum to the purified $A C h R$ from denervated rat muscle was measured by incubating $91 \mathrm{fmol}$ of AChR or of toxin-receptor complex with antibody at $4^{\circ} \mathrm{C}$ overnight in $10 \mathrm{~mm}$ Tris, $1 \%$ Triton X-100,1 mg/ml of BSA, pH 7.4 (final volume, 25 or $30 \mu \mathrm{l})$. After the incubation, $5 \mu$ l of $50 \mathrm{~nm}\left[{ }^{125}\right]$ ]- $\alpha$-BuTx were added to tubes containing receptor, which were then incubated at $37^{\circ} \mathrm{C}$ for $60 \mathrm{~min}$. PBS-BSA $(75 \mu \mathrm{l})$ was added to all tubes, followed by $2 \mu$ l of a rabbit antiserum raised to a DEAE fraction of the myasthenic antibodies. After incubation at room temperature, $75 \mu \mathrm{l}$ of immobilized protein A were added, and the incubation continued for $30 \mathrm{~min}$. The tubes were centrifuged, the pellets were washed, and the radioactivity in the pellets was measured with a Beckman gamma counter. 
Immunocytochemistry. Frozen sections $(4 \mu \mathrm{m})$ of rat and chicken muscle were cut on a cryostat as described by Sanes and Hall (1979). Muscles from young rats were sandwiched between pieces of adult diaphragm before freezing. Muscle sections were incubated with $2 \mathrm{mg} / \mathrm{ml}$ of a DEAE fraction of myasthenic serum prepared as above, followed by a mixture of fluoresceinconjugated goat anti-human lgG Fab fragment (N. L. Cappel Laboratories) and rhodamine-labeled $\alpha$-BuTx. Sections were examined under fluorescein and rhodamine optics in a Leitz Diavert fluorescence microscope. Further details of the immunocytochemical procedures were as described (Sanes and Hall, 1979; Bloch and Hall, 1983).

\section{Results and Discussion}

Patients with myasthenia gravis have two types of antibodies in their sera: antibodies that recognize one or more determinants on extrasynaptic AChRs that are not present on AChRs at adult synapses, and antibodies that do not distinguish the two receptor types (Weinberg and Hall, 1979). To obtain a serum that was enriched in the first class of antibodies, we screened sera from myasthenic patients for their ability to distinguish AChRs purified from normal and denervated adult rat muscles. We wished to use the antibodies as immunocytochemical reagents to study selectively the AChRs at endplates. Therefore, we sought antibodies, similar to those described by Dwyer et al. (1981), that would block the binding of $\alpha$ BuTx. Since the toxin-binding site is exposed on the external cell surface, antibodies that recognize this site should be well suited for immunocytochemistry.

Of 35 sera screened, one was remarkably specific. When tested against AChRs from rat or mouse muscles, antibodies in this serum recognized only AChRs from denervated or embryonic muscle. Thus, the serum had no effect on the binding of [ [25I]- $\alpha$-BuTx to AChRs purified from normal rat muscle, but it inhibited the binding of toxin to AChR purified from denervated muscle (Fig. 1). Similar results were obtained when AChRs prepared from adult mouse muscle and from the myotubes of C2 (Yaffe and Saxel, 1977; Inestrosa et al., 1983), a mouse-muscle cell line, were compared. The antibody blocked toxin binding to C2 AChRs but not to those from adult mouse muscle (data not shown). In the case of extrajunctional AChRs from both rat (Fig. 1) and mouse, inhibition was to a

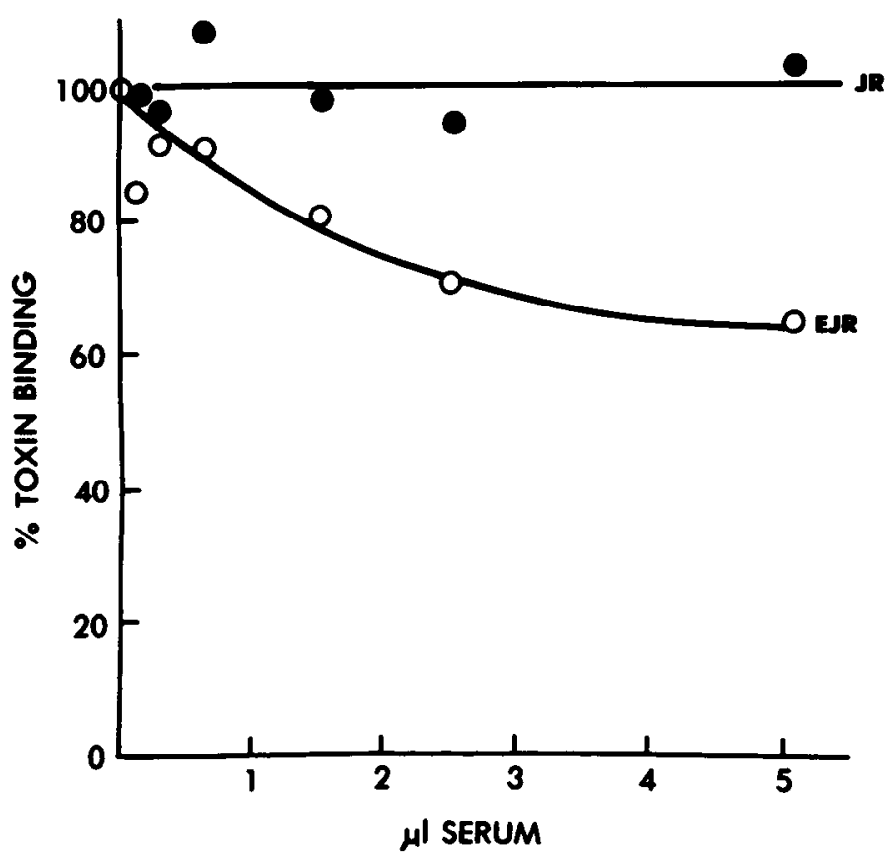

Figure 1. Myasthenia gravis serum inhibits binding of $\left[{ }^{125} \mid-\alpha-B u T x\right.$ to $A C h R$ purified from denervated rat muscle, but not from normal rat muscle. AChRs (125 fmol) purified from normal $(J R)$ or denervated $(E J R)$ rat leg muscle were incubated with the indicated amount of serum and subsequently assayed for toxin-binding activity as described under "Materials and Methods." maximum value of approxiamtely $50 \%$. Only partial inhibition is achieved because the antibody recognizes only one of the two toxin-binding sites that each AChR possesses (Gu et al., 1985).

Binding of the antibodies in the myasthenic serum to the AChR could be measured directly by incubating the AChR from denervated muscle sequentially with the serum, with $\left.\left[{ }^{125}\right]\right]-\alpha$-BuTx to label the $A C h R$, and with either a second antibody or immobilized protein $A$ to precipitate the AChR bound to antibody (Fig 2). No binding to AChRs from normal adult muscle was detected by this assay. When extrajunctional AChRs were incubated with $\left[{ }^{125}\right]$ ] $\alpha$-BuTx prior to incubation with the myasthenic antibody, the toxin blocked over $95 \%$ of the binding of antibody to the AChR (Fig. 3). Thus, virtually the only antibodies for rat receptor present in this serum are those that bind at or near a toxin-binding site on the extrajunctional receptor.

We used this serum to examine the AChRs at endplates in developing rat muscle. Cryostat sections of rat diaphragm were exposed to the myasthenic antibodies, followed by a fluorescein-

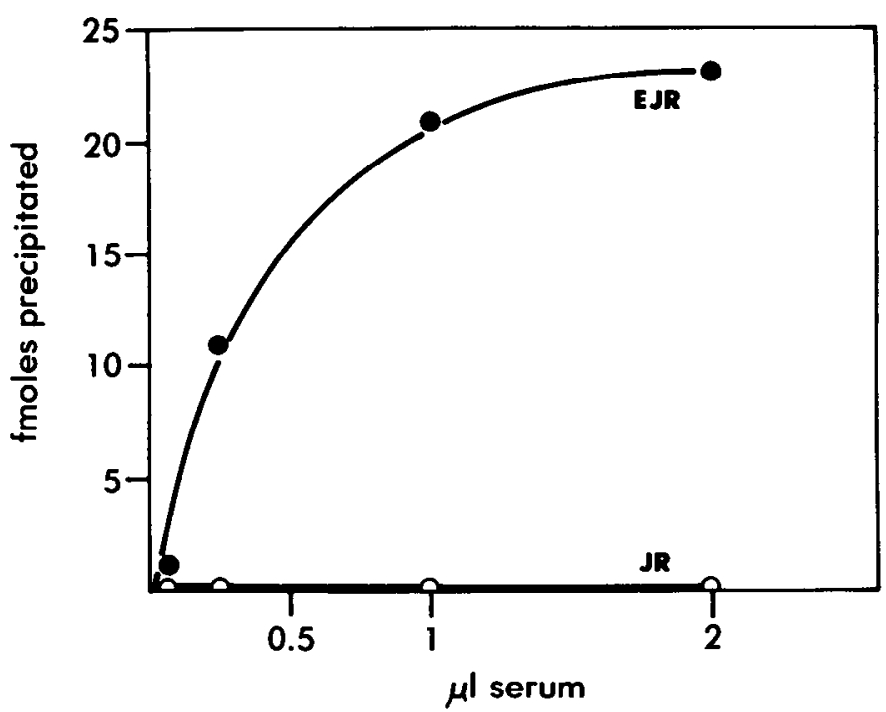

Figure 2. Myasthenia gravis serum binds to AChR purified from denervated rat muscle $(E J R)$, but not to $A C h R$ purified from normal rat muscle $(J R)$. AChRs were incubated with the indicated amount of serum, and after precipitation with immobilized protein $A$, the supernatant was assayed for AChR as described under "Materials and Methods."

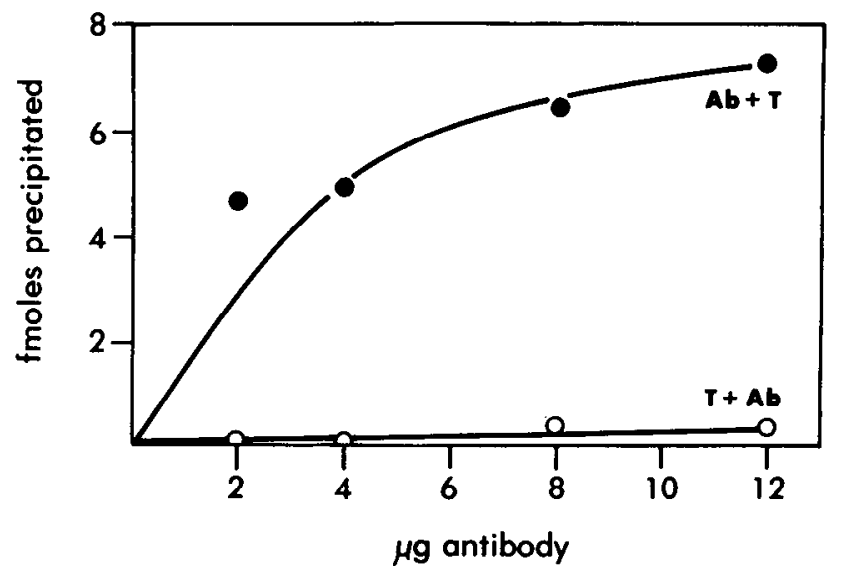

Figure 3. The binding of myasthenic antibodies to AChR purified from denervated rat muscle is blocked by $\alpha$-BuTx. AChR was either incubated with myasthenic antibody followed by $\left[{ }^{125}\right]-\alpha$-BuTx $(A b+T)$ or with $\left.\left[{ }^{125}\right)\right]-\alpha$ BuTx followed by myasthenic antibody $(T+A b)$. A rabbit antiserum to the myasthenic antibodies was then added, followed by immobilized protein $A$. The radioactivity in the precipitate was then determined. Details of the procedure are given under "Materials and Methods." 


\section{Postnatal Age (days)}

$M G A b$
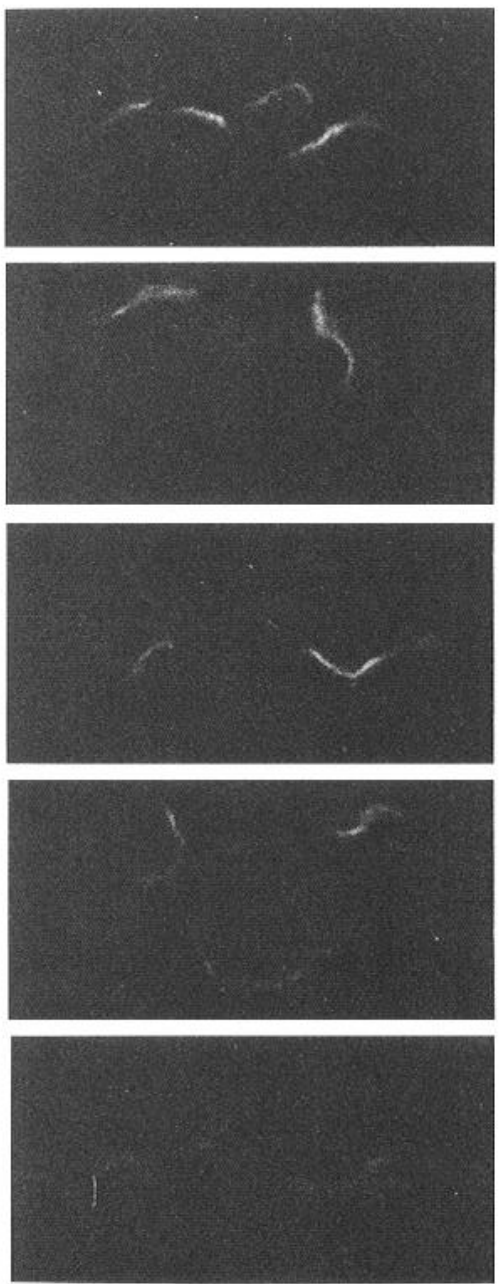

\section{$a-B u T x$}
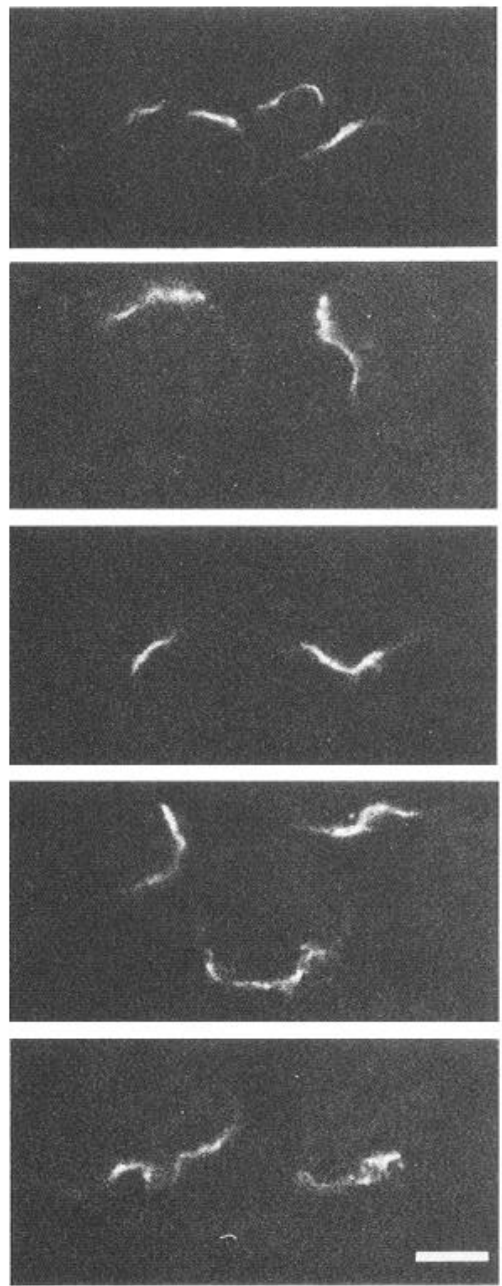

Figure 4. Binding of myasthenia gravis antibody $(M G A b)$ to $A C h R s$ at endplates in developing rat muscle declines during the second and third postnatal weeks. Sections of rat diaphragm muscle from postnatal rats of varying ages were viewed with fluorescein optics and rhodamine optics after incubation with a DEAE fraction of myasthenic serum, followed by a mixture of fluorescein-conjugated second antibody and rhodamine-labeled $\alpha$-BuTx. Exposure and printing conditions were the same for all ages. The very faint residual staining seen in day 18 muscles could correspond to the faint "nonspecific" staining of endplates that is sometimes seen with normal human sera (L. Silberstein and Z. W. Hall, unpublished observations).

conjugated second antibody. Because toxin binding was only partially blocked by the serum, rhodamine-labeled $\alpha$-BuTx could be used to locate the AChRs at endplates. AChRs at endplates in neonatal rats bound antibody, as did endplate AChRs in 6-day-old rats. At the ages of 10 and 14 days, binding was progressively decreased and was virtually absent at endplates of 18-day-old rats (Fig. 4). To establish that the antibodies seen by immunocytochemistry have the same specificity as those that bind the solubilized receptor (Silberstein et al., 1983), we incubated muscle sections from 6- or 10-day-old animals with rhodamine $\alpha$-BuTx before adding the myasthenic antibody. Under these conditions, staining with antibody was almost completely eliminated (Fig. 5a). Thus, during the second and third postnatal weeks, AChRs at endplates undergo an immunological transition involving a determinant at or near a toxin-binding site on the receptor.

The change in immunological properties that occurs during development is not synchronous with $\mathrm{AChR}$ clustering or with the change in metabolic turnover time of endplate AChRs, as both of these events occur prenatally. The immunological change is, however, temporally correlated with the change in channel properties of the AChR and with the appearance of folds in the postsynaptic membrane. The mean channel open time $(\tau)$ of the AChR at rat muscle endplates changes postnatally from a value of 3 to $4 \mathrm{msec}$ to one of about $1 \mathrm{msec}$. AChRs with short channel open times first can be detected at endplates in rat diaphragm at postnatal day 6 (Sakmann and Brenner, 1978; Fischbach and Schuetze, 1980). Their proportion increases over the next 7 days until all endplate AChRs have fast channels. In contrast, in the rat soleus, the channel open time decreases between 8 and 18 days after birth, in a process that has been estimated to occur with a half-time of 3 to 4 days (Michler and Sakmann, 1980). During the same development period in rat and mouse muscle in which the channel open time decreases, the surface area of the endplate increases and deep junctional folds begin to form (Teravainen, 1968; Kelly and Zacks, 1969).

Using a different myasthenic serum to analyze the total AChR population in crude extracts of developing rat muscle, we previously reported an immunological change in AChRs as early as the second postnatal day (Reiness and Hall, 1981). Whether this discrepancy between our previous and present results arises from different specificities of the two sera that we have used, or represents different sensitivities of the two methods, remains to be determined. Because channels with adult properties had not been reported to occur at 

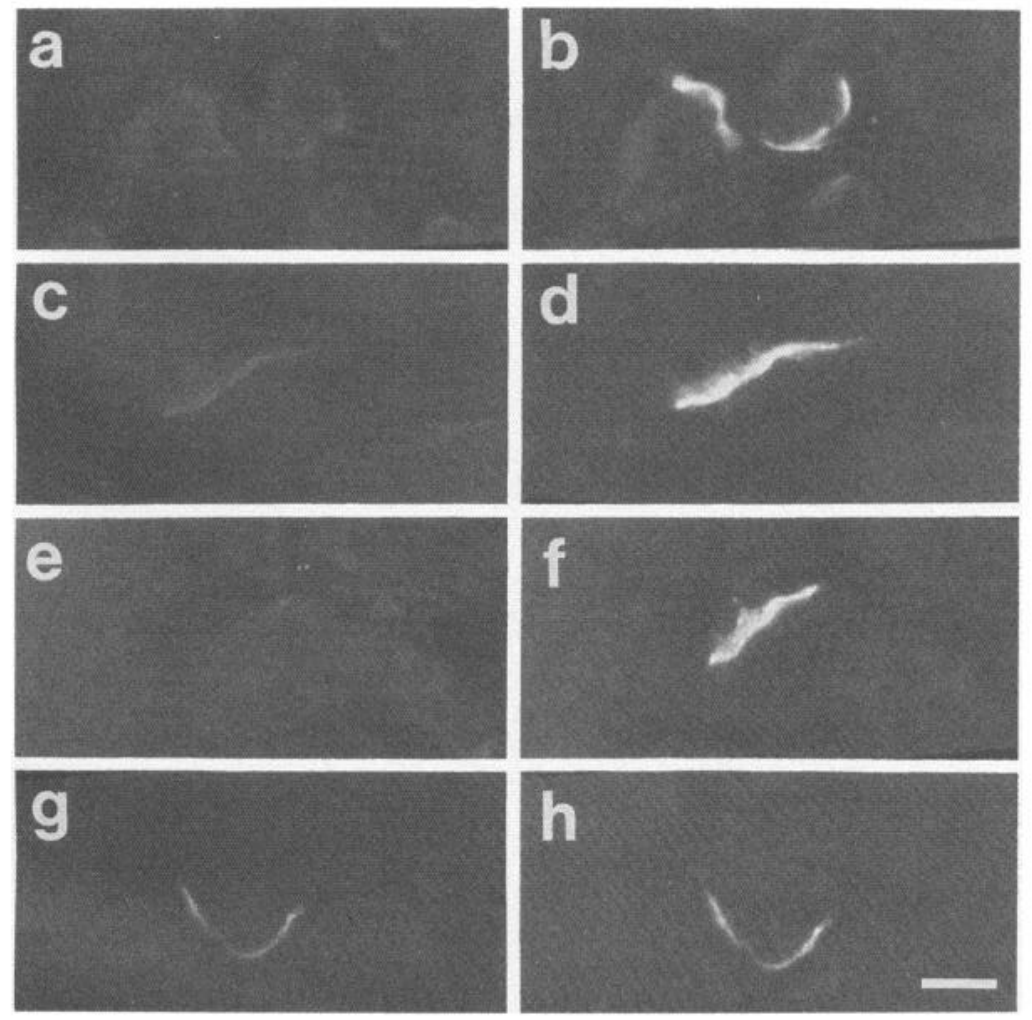

Figure 5. Binding of antibody to AChRs at rat and chicken endplates. Cryostat sections were incubated with the DEAE fraction of the myasthenic serum, followed by fluorescein-conjugated second antibody and rhodamine-labeled $\alpha$-BuTx. Sections were then photographed with fluorescein $(a, c, e$, and $g$ ) or rhodamine $(b, d, f$, and $h$ ) optics. In $a$ and $b$ the sections were incubated with rhodamine-labeled $\alpha$-Butx before the antibody. In all other cases, the sections were exposed to the myasthenic antibody before the toxin. $a$ and $b$, Sections of diaphragm from a 6-dayold rat. $c$ and $d$, Sections from a denervated (21 days) rat diaphragm. $e$ and $f$, Sections from a normal rat diaphragm. $g$ and $h$, Sections from adult chicken anterior latissimus dorsi muscle. Bar, $10 \mu \mathrm{m}$.
TABLE I

Properties of the endplate AChRs and the postsynaptic membrane in developing and adult muscle ${ }^{a}$

\begin{tabular}{lcccc}
\hline \multicolumn{1}{c}{ Muscle } & $\begin{array}{c}\text { AChR } \\
\text { Metabolic } \\
\text { Turnover Time }\end{array}$ & $\begin{array}{c}\text { Prominent }^{b} \\
\text { Folds }^{c}\end{array}$ & $\begin{array}{c}\text { AChR } \\
\text { Channel } \\
\text { Open Time }\end{array}$ & $\begin{array}{c}\text { Immunological } \\
\text { Reactivity }\end{array}$ \\
\hline $\begin{array}{c}\text { Neonatal rat dia- } \\
\text { phragm }\end{array}$ & slow & - & long & ++ \\
$\begin{array}{c}\text { Adult rat diaphragm } \\
\begin{array}{c}\text { Denervated adult rat } \\
\text { diaphragm }\end{array}\end{array}$ & slow & + & short & - \\
$\begin{array}{c}\text { Adult chicken anterior } \\
\text { latissimus dorsi }\end{array}$ & slow & - & long & $+1-$ \\
\hline
\end{tabular}

${ }^{a}$ Table I is from Hall et al. (1983); used with permission from Cold Spring Harbor Laboratory, (c) 1983.

${ }^{\circ}$ Sources: Berg and Hall, 1975; Burden, 1977; Reiness and Weinberg (1981): Loring and Salpeter (1980); Brett et al. (1982).

' Sources: Teravainen (1968); Kelly and Zacks (1969); Miledi and Salter (1969); Atsumi (1977).

${ }^{\circ}$ Sources: Sakmann and Brenner (1978); Michler and Sakmann (1980); Fischbach and Schuetze (1980); Brenner and Sakmann (1983); Schuetze (1980).

endplates as early as the second postnatal day (Sakmann and Brenner, 1978; Fischbach and Schuetze, 1980), we previously suggested that the transition in immunological properties was not related to channel open time. According to more recent estimates, however, endplate AChRs with altered channels can be found as early as 2 days after birth (S. M. Schuetze and S. Vicini, personal communication), so that our interpretation of the present results is not necessarily at variance with our previous findings.

To examine further the relationship between immunological reactivity and other properties, we also tested endplates in rat muscles that had been denervated for 21 days. AChRs at these endplates showed only faint binding of the myasthenic antibodies (fig. 5, C and $D$ ). Synaptic folds are maintained for many weeks in denervated rat muscles (Miledi and Slater, 1969), and the mean channel open time of the AChRs remains short (Brenner and Sakmann, 1983). However, their metabolic turnover time is changed; after denervation, AChRs that turn over rapidly replace those that turn over slowly (Loring and Salpeter, 1980; Brett et al., 1982). Thus, in developing and denervated rat muscle, immunological reactivity is associated with a lack of folds and a long mean channel open time, and is independent of metabolic turnover time (Table I). The correlation between synaptic folds, mean channel open time, and the immunological properties of the AChR is further strengthened by examination of an adult chicken muscle, the anterior latissimus dorsi. Endplates in this muscle lack prominent folds (Atsumi, 1977); the mean channel open time of the AChRs (3 to $4 \mathrm{msec}$ ) does not change during development (Schuetze, 1980); and, in contrast to the rat (Fig. 5, $e$ and $f$ ), the AChRs at adult synapses are bound by antibodies in the myasthenic serum (Fig. 5, $g$ and $h$ ).

During development, rat muscle AChRs undergo a postnatal change in their pharmacology. Curare depolarizes AChRs in embryonic and neonatal muscle but is an antagonist in muscles taken from animals during the second and third weeks after birth (Ziskind and Dennis, 1978; Trautmann, 1982). This transition has so far been demonstrated only for AChRs in the extrajunctional muscle membrane. Whether it also occurs at endplates, and whether it is related to the changes described here, is not known. AChRs at adult endplates and the AChRs in the extrajunctional membrane of denervated and developing muscles also differ in their pl (Brockes and Hall, 1975). Because the AChRs at endplates in the diaphragms of neonatal rats have a pl that is characteristic of the AChRs at adult endplates (Brockes and Hall, 1975), the results presented here imply that these receptors must represent a form that is intermediate between the extrajunctional AChRs of embryonic muscle and those of the adult endplate, i.e., a form with the pl of AChRs in adult muscle and the immunological properties of AChRs in embryonic muscle. Thus, the simple division of AChRs into junctional and extrajunctional forms based on biochemical properties is not an appropriate one.

The postnatal change in immunological reactivity of the AChR in rat muscles suggests that the receptors at endplates undergo a 
developmental transition in isoforms (Caplan et al., 1983) similar to those described for globin (Weatherall and Clegg, 1979), $\alpha$-fetoprotein (Law and Dugaiczyk, 1981), and several other proteins (Garrels and Gibson, 1976; Whalen et al., 1976; Perriard et al., 1978; Lowey et al., 1982; Crow et al., 1983). One example of particular interest is the sequential appearance in developing fast muscles in the rat of three different isozymes of myosin heavy chain (Whalen et al., 1981). The last step in this sequence is the replacement of a neonatal form of myosin by the adult form. Interestingly, this transition, like that in the immunology of the AChR, occurs during the second and third postnatal weeks. This period is also the time during which the multiple innervation that is characteristic of developing muscle fibers is reduced to innervation of each fiber by a single neuron (Redfern, 1970; Brown et al., 1976). Changes in muscle activity or in the influence of neuronal factors brought about by the loss of innervation could provide the trigger for the biochemical changes that occur at the endplate and elsewhere during the postnatal stage of muscle development.

\section{References}

Almon, R. R., and S. H. Appel (1975) Interaction of myasthenic serum globulin with the acetylcholine receptor. Biochim. Biophys. Acta 393: 66-77.

Atsumi, S. (1977) Development of neuromuscular junctions of fast and slow muscles in the chick embryo: A light and electron microscopic study. J. Neurocytol. 6: 691-709.

Berg, D. W. and Z. W. Hall (1975) Loss of $\alpha$-bungarotoxin from junctional and extrajunctional acetylcholine receptors in rat diaphragm muscle in vivo and in organ culture. J. Physiol. (Lond.) 252: 771-789.

Bevan, S., and J. H. Steinbach (1977) The distribution of $\alpha$-bungarotoxin binding sites on mammalian skeletal muscle developing in vivo. J. Physiol. (Lond.) 267: 195-213.

Bloch, R., and Z. W. Hall (1983) Cytoskeletal components of the vertebrate neuromuscular junction: Vinculin, alpha-actinin, filmamin and myosin. J. Cell Biol. 97: 217-223.

Braithwaite, A. W., and A. J. Harris (1979) Neural influence on acetylcholine receptor clusters in embryonic development of skeletal muscles. Nature 279: 549-551.

Brenner, H. R., and B. Sakmann (1983) Neurotrophic control of channel properties at neuromuscular synapses of rat muscie. J. Physiol. (Lond.) 337: 159-171.

Brett, R. S., S. G. Younkin, M. Konieczkowski, and R. M. Slugg (1982) Accelerated degradation of junctional acetylcholine receptor- $\alpha$-bungarotoxin complexes in denervated rat diaphragm. Brain Res. 233: 133-142.

Brockes, J., and Z. W. Hall (1975) Acetylcholine receptors in normal and denervated rat diaphragm muscle. II. Comparison of junctional and extrajunctional receptors. Biochemistry 14: 2100-2106.

Brown, M. C., J. K. S. Jansen, and D. C. Van Essen (1976) Polyneuronal innervation of skeletal muscle in new-born rats and its elimination during maturation. J. Physiol. (Lond.) 261: 387-422.

Burden, S. (1977) Development of the neuromuscular junction in the chick embryo: The number, distribution, and stability of acetylcholine receptors. Dev. Biol. 57: 317-329.

Caplan, A. I., M. Y. Fiszman, and H. M. Eppenberger (1983) Molecular and cell isoforms during development. Science 221: 921-927.

Crow, M. T., P. S. Olson, and F. E. Stockdale (1983) Myosin light chain expression during avian muscle development. J. Cell Biol. 96: 736-744.

Dennis, M. J. (1981) Development of the neuromuscular junction: Inductive interactions between cells. Annu. Rev. Neurobiol. 4: 43-68.

Dennis, M. J., L. Ziskind-Conhaim, and A. J. Harris (1981) Development of neuromuscular junctions in rat embryo. Dev. Biol. 81: 266-279.

Dwyer, D. S., R. L. Bradley, L. Furner, and G. E. Kemp (1981) Immunochemical properties of junctional and extrajunctional acetylcholine receptor. Brain Res. 217: 23-40.

Fambrough, D. M. (1979) Control of acetylcholine receptors in skeletal muscle. Physiol. Rev. 59: 165-227.

Fischbach, G. D., and S. M. Schuetze (1980) A postnatal decrease in acetylcholine channel open time at rat endplates. J. Physiol. (Lond.) 303: 125-138.

Froehner, S. C., C. G. Reiness, and Z. W. Hall (1977) Subunit structure of the acetylcholine receptor from denervated rat skeletal muscle. J. Biol. Chem. 252: 8589-8596.
Garrels, J. I., and W. Gibson (1976) Identification and characterization of multiple forms of actin. Cell 9: 793 .

Gu, Y., L. Silberstein, and Z. W. Hall. (1985) The effects of a myasthenic serum on the acetylcholine receptors of $\mathrm{C} 2$ myotubes. I. Immunological distinction between the two toxin-binding sites of the receptor. J. Neurosci., in press.

Hall, Z. W., M. P. Roisin, Y. Gu, and P. Gorin (1983) A developmental change in the immunological properties of acetylcholine receptors at the rat neuromuscular junction. Cold Spring Harbor Symp. Quant. Biol. 48: 101108 .

Inestrosa, N. C., J. B. Miller, L. Silberstein, L. Ziskind-Conhaim, and Z. W. Hall (1983) Developmental regulation of $16 \mathrm{~S}$ acetylcholinesterase and acetylcholine receptors in a mouse cell line. Exp. Cell Res. 147: 393-405.

Kelly, A. M., and S. I. Zacks (1969) The fine structure of motor endplate morphogenesis. J. Cell Biol. 42: 154-169.

Law, S. W., and A. Dugaiczyk (1981) Homology between the primary structure of $\alpha$-fetoprotein, deduced from a complete cDNA sequence, and serum albumin. Nature 291: 201-205.

Loring, R. H., and M. M. Salpeter (1980) Denervation increases turnover rate of junctional acetylcholine receptors. Proc. Natl. Acad. Sci. U. S. A. 77: 2293-2298

Lowey, S., P. A. Benfield, D. D. LeBlanc, G. Waller, D. A. Winkelmann, and G. F. Gauthier (1982) Characterization of myosins from embryonic and developing chicken pectoralis muscle. In Muscle Development, Molecular and Cellular Control, M. L. Pearson and H. F. Epstein, eds., pp. 15-24, Cold Spring Harbor Laboratory, Cold Spring Harbor, NY.

Michler, A., and B. Sakmann (1980) Receptor stability and channel conversion in the subsynaptic membrane of the developing mammalian neuromuscular junction. Dev. Biol. 80: 1-17.

Miledi, R., and C. R. Slater (1969) Electron-microscopic structure of denervated skeletal muscle. Proc. R. Soc. Lond. (Biol.) 174: 253-269.

Nathanson, N. M., and Z. W. Hall (1979) Subunit structure and peptide mapping of junctional and extrajunctional acetylcholine receptors from rat muscle. Biochemistry 15: 3392-3401.

Perriard, J. C., M. Caravatti, E. R. Perriard, and H. M. Eppenberger (1978) Detection and relative quantitation of mRNA for creatine kinase isoenzymes in RNA from myogenic cell cultures and embryonic chicken tissues. J. Biol. Chem. 253: 6529.

Redfern, P. A. (1970) Neuromuscular transmission in new-born rats. J. Physiol. (Lond.) 209: 701-709.

Reiness, C. G., and Z. W. Hall (1981) The developmental change in immunological properties of the acetylcholine receptor in rat muscle. Dev. Biol. 81: 324-331.

Reiness, C. G., and C. B. Weinberg (1981) Metabolic stabilization of acetylcholine receptors at newly formed neuromuscular junctions in rat. Dev. Biol. 84: 247-254.

Sakmann, B., and H. R. Brenner (1978) Changes in synaptic channel gating during neuromuscular development. Nature 274: 68-70.

Sanes, J. R., and Z. W. Hall (1979) Antibodies that bind specifically to synaptic sites on muscle fiber basal lamina. J. Cell Biol. 83: 357-370.

Schuetze, S. M. (1980) The acetylcholine channel open time in chick muscle is not decreased following innervation. J. Physiol. (Lond.) 303: 111-124.

Silberstein, L., P. D. Gorin, and Z. W. Hall (1983) Differentiation of the acetylcholine receptor at developing neuromuscular junctions. In FifthInternational Congress on Neuromuscular Diseases, Marseilles, G. Serratrice, D. Cros, and D. Desnuelle, eds.

Teravainen, $H$. (1968) Development of the myoneural junction in the rat. $Z$. Zellforsch. 87: 249-265.

Trautmann, A. (1982) Curare can open and block ionic channels associated with cholinergic receptors. Nature 298: 272-275.

Weatherall, D. J., and J. B. Clegg (1979) Recent developments in the molecular genetics of human hemoglobin. Cell 16: 467-479.

Weinberg, C. B., and Z. W. Hall (1979) Antibodies from patients with myasthenia gravis recognize determinants unique to extrajunctional recep. tors. Proc. Natl. Acad. Sci. 76: 504-508.

Whalen, R., G. S. Butler-Browne, and F. Gros (1976) Protein syntheis and actin heterogeneity in calf muscle cells in culture. Proc. Natl. Acad. Sci. U. S. A. 73: 2018.

Whalen, R. G., S. M. Sell, G. S. Butler-Browne, K. Schwartz, P. Bouveret, and 1. Pinset-Harstrom (1981) Three myosin heavy chain isozymes appear sequentially in rat muscle development. Nature 292: 805-809.

Yaffe, D., and O. Saxel (1977) Serial passaging and differentiation of myogenic cells isolated from dystrophic mouse muscle. Nature 270: 725727.

Ziskind, L., and M. J. Dennis (1978) Depolarizing effects of curare on embryonic rat muscles. Nature 276: 622-623. 